\title{
Should judges be neutral?
}

\author{
Gerard Hogan*
}

Advocate General, Court of Justice, Luxembourg

\section{INTRODUCTION: SHOULD JUDGES BE NEUTRAL IN THE SENSE OF AN INDIFFERENCE TO THE OUTCOME OF A CASE?}

$\mathrm{W}$ riting in the aftermath of the tragic space shuttle Challenger disaster in 1986, the great American physicist and Nobel laureate, Richard Feynmann, famously observed that for a successful technology 'reality must take precedence over public relations for Nature cannot be fooled'. ${ }^{1}$ By this he meant that there were immutable scientific laws which could not be wished away or somehow glossed over. Is there, I wonder, a lesson here for lawyers and judges as well?

Even though law is a purely human construct and not a natural science, for at least 150 years judges have generally sought to emulate the scientific method of rigorous, detached reasoning even if this method of reasoning sometimes leads to results which are surprising, unwelcome and inconvenient. Feynmann's essential point was that in a scientific context such conclusions cannot be ignored or discounted just because they are unwelcome or inconvenient. But do judges as guardians of a human system enjoy a freedom denied by Nature to scientists? Can we elect to avoid conclusions which might be unwelcome or inconvenient, irrespective of whether this is done for reasons of pragmatism or because such a conclusion offends our own sense of justice? Or is it the case that, just as with Nature, she who Cardozo famously described as 'Our Lady of the Common Law'2 cannot be fooled?

The question I want to pose this evening accordingly is whether judges should be neutral. There is no question at all but that it is possible that they can be neutral in the sense of disregarding their own personal preferences or views as to the desirability of the outcome. Two recent appointees to the US Supreme Court have made this point

* This is a slightly revised version of the MacDermott Lecture delivered (virtually) at Queen's University, Belfast, on 27 May 2021. I owe particular thanks to The Right Honourable Sir Declan Morgan, Lord Chief Justice of Northern Ireland, Professor Christopher McCrudden, Professor Brice Dickson, Hon Mr Justice Sean Ryan and Dr David Capper.

1 Report of the (Rogers) Presidential Commission on the Space Shuttle Challenger Accident, vol 2, appendix F.

2 Benjamin N Cardozo, 'Our Lady of the Common Law' (1939) 13 St John's Law Review 231. 
rather well in the course of their respective confirmation processes. In her speech immediately preceding her taking the declaration of office, Coney Barrett $J$ said that the most important feature of judicial independence was the independence from one's own personal views. And Gorsuch J said at his Senate confirmation hearing that:

I have decided cases for Native Americans seeking to protect tribal lands ... for victims of nuclear waste pollution ... for disabled students, prisoners and workers alleging civil rights violations. Sometimes, I have ruled against such persons too. But my decisions have never reflected a judgment about the people before me - only my best judgment about the law and the facts at issue in each particular case. For the truth is, a judge who likes every outcome he reaches is probably a pretty bad judge, stretching for policy results he prefers rather than those that the law compels. ${ }^{3}$

Lord MacDermott would, I am sure, have approved of these sentiments. After all, he found for the punter in Hill $v$ William Hill (Park Lane) $L t d^{4}$ in holding that the money which the bookmaker sought to recover was an irrecoverable gaming debt and even though - in Lord Lowry's memorable words - this must have been 'Lord MacDermott's closest ever contact with a bookmaker'. ${ }^{5}$

There is, of course, another sense in which judges are not and cannot be expected to be neutral. Judges are not neutral about legal values or matters which are part of the core constitutional identity of their own State. The UK Supreme Court is not, for example, neutral about the great legal inheritance that is the common law. One may expect that that Court will see that it is under a duty to ensure that these principles remain vibrant for the modern legal world. South of the border, the Irish Supreme Court is not neutral about upholding the values and principles contained in the Irish Constitution. Indeed, if it were not to go about the business of developing and integrating these values and rules into the legal system it would come under criticism. And much the same can be said in turn for courts in Luxembourg, Strasbourg, Karlsruhe, Rome, Washington DC and elsewhere. This question of ultimate legal and constitutional identity - and which court is under a duty to protect it - is currently the subject of extensive debate between the German ${ }^{6}$

3 John Greenya, Gorsuch: The Judge who Speaks for Himself (Threshold Editions 2017) 210.

4 [1949] AC 530.

5 Lord Lowry, 'The Irish Lords of Appeal in Ordinary' in D Greer and N Dawson (eds), Mysteries and Solutions in Irish Legal History (Four Courts 2001) 213.

6 See, eg, judgment in the Bond Buying case of 5 May 20202 BvR 85915 and see, generally, J-M Perez de Nanclares, 'Verfassungsgerichtliche Kooperation in europäischen Rechtsraum’ in von Bogdandy, C Grabenwarter and P Huber (eds), Handbuch Ius Publicum Europaeum - Verfassungsgerichtsbarkeit in Europa (Max Plank Institute 2021) 539-619. 
and Italian Constitutional Courts, ${ }^{7}$ on the one hand, and the Court of Justice on the other. That is a fascinating debate in its own right, but it is not the subject of my discourse this evening.

My query is rather whether judges should be neutral in the sense of a blithe indifference to the outcome. Or should judges instead have regard to the outcome in making decisions so that, so to speak, they reason backwards from the desired result instead of the reverse? And is this not what judges do anyway a good deal of the time, even if this is not often admitted? These, of course, are not new or novel ideas. For over 100 years legal realists have argued that the orthodox theory of judging was wrong because in Dworkin's words, it had taken:

... a doctrinal theory to jurisprudence, attempting to describe what judges do by concentrating on the rules they mention in their decision. This is an error, the realists argued, because judges actually decide cases according to their own political or moral tastes, and choose an approximate legal rule as a rationalisation. The realists asked for a 'scientific' approach that would fix on what judges do, rather than what they say, and the actual impact their decisions have on the larger community. 8

This point was well expressed by Ryan P - the former President of the Republic's Court of Appeal - in a scintillating post-retirement lecture. He made the point that it was important for the barrister to know the 'form' of the type of judge before whom the case was assigned and the key role of the identity of that judge:

The Tammany Hall politician who said: 'Don't tell me what the law says, tell me who the judge is' is accurately enough reflecting the role that I played as a barrister. Most practitioners in the common law world of personal injuries - long the dominant category of litigation-and nonjury actions considered themselves experts on the inarticulate major premises of the judges before whom they appeared. Barristers operated like share analysts or, perhaps, more accurately like punters selecting likely winners. Holmes's man in the State penitentiary did not want to know the law; just like my clients, he wanted to know the likely outcome. That I think is pragmatism at work. The business of the bar is not law, but cases and judges. 9

It is idle to deny that these observations contain at least a lot of truth, even if they are not perhaps the full picture. It is nonetheless

7 See, eg, Case C-105/14 Taricco EU:C: 2015: 555, Case C-42/17 MAS EU:C:2017:936, judgment of the Italian Constitutional Court of 10 April 2018 115/2018 and see, generally, G Piccirilli, 'The Taricco Saga: the Italian Constitutional Court continues its European Journey' (2018) 14 European Constitutional Law Review 814.

$8 \quad$ R Dworkin, Taking Rights Seriously (Duckworth 1977) 3.

9 Mr Justice Sean Ryan, 'Confessions of a pragmatist', Vivian Lavan Lecture (UCD Law Society 2019). I am very grateful to Mr Justice Ryan for supplying me with the text of this lecture. 
striking that there are very few judges who openly admit to this in their judgments. How often does one hear a judge - even the 'Completely Adult Jurist' originally posited by the avowed leader of the realist school, Jerome Frank ${ }^{10}$ - openly say that he or she decides cases by reference to their own political or social views and then later chooses an approximate legal rule as a rationalisation for that decision? Indeed, the only 'completely adult jurist' then recognised by Frank - Holmes J - appeared to say the exact opposite when he declared in a letter to Harold Laski that 'if my fellow citizens want to go to Hell, I will help them. It's my job.'11

One of the rare instances where a judge openly said that the consequences of a decision should be considered was the following account of what the then President of the Irish High Court, Kearns P, said in a speech on his retirement:

Mr Justice Kearns said judges should never put themselves in the position of realising, too late, that a particular decision has opened a Pandora's Box of unintended consequences which if proper consideration had been applied, might have led to a different approach being taken. He said this was particularly the case where the boundaries of judicial and executive function intersected. ${ }^{12}$

This, however, was in the course of a retirement speech and was not contained in an actual judgment. Post-retirement Lord Sumption expressed similar views, albeit with an important caveat:

Almost all judges start from an intuitive answer and work backwards. Most of them, however, recoil in the face of intellectual difficulty or constitutional principle. ${ }^{13}$

But, if is this what judges actually $d o$, why do they generally seem reluctant to admit to this?

\section{SHOULD JUDGES STRIVE TO AVOID CONSEQUENCES WHICH THEY (SUBJECTIVELY) CONSIDER ARE NOT IN THE PUBLIC INTEREST?}

For those of us of a certain age, the decline of Lord Denning - still, on any view, one of the greatest ever English judges - was in some respects painful to watch. By the end of the late 1970s Denning's tussles with

10 Jerome Frank, Law and the Modern Mind (MIT Press 1930) ch 4.

11 Mark De Wolfe Howe (ed), Holmes-Laski Letters vol 1 (Harvard University Press 1953) 249.

12 Quoted by Richard Humphreys, 'The Constitution and law as living instruments for a living society' (2017) 40 Dublin University Law Journal 45, 63.

13 Lord Sumption, 'Covid-19 and the courts: expediency or law?' (2021) 137 Law Quarterly Review 353, 357. 
the House of Lords had become the stuff of legend. But it is probably sufficient for this purpose to refer to the series of trade union decisions in the late 1970s and the early 1980s which culminated in Duport Steels $v$ Sirs. ${ }^{14}$ By this stage Lord Denning - spurred on by a wholly understandable reaction to trade union excesses - was taking his fellow judges in the Court of Appeal down a road which led ultimately to a repudiation of the authority of the Law Lords ${ }^{15}$ and, worse again, the authority of Parliament, given that the doctrine of parliamentary sovereignty was then (and, perhaps, still is) a key feature of the UK constitutional regime. In Duport Steels Lord Scarman spelt this out when allowing the appeal from Lord Denning's decision:

My basic criticism of all three judgments in the Court of Appeal is that in their desire to do justice the court failed to do justice according to law ... Unpalatable statute law may not be disregarded or rejected, merely because it is unpalatable ... ${ }^{16}$

While acknowledging that, within certain limits, judges have a genuine creative role 'as the remarkable judicial career of Lord Denning himself shows', Lord Scarman went on:

Great judges are in their different ways judicial activists. But the constitution's separation of powers must be observed if judicial independence is not to be put at risk. For, if people and Parliament come to think that the judicial power is to be confined by nothing other than the judge's sense of what is right ... confidence in the judicial system will be replaced by fear of it becoming uncertain and arbitrary in its application. ${ }^{17}$

In passing it may be observed that this passage from Lord Scarman is itself a notable exposition of the importance of judicial neutrality.

14 [1980] 1 WLR 142.

15 In Express Newspapers $v$ McShane [1980] AC 672 the House of Lords had held that the test as to whether a particular act had been done in furtherance of a trade dispute (and, hence, to attract a statutory immunity) was purely subjective. In the Court of Appeal in Duport Steels, Lord Denning said of the House of Lords judgment in McShane: 'We have gone through that case and read the judgments. They are not nearly so clearly on the point as some would believe ...'.

On appeal, however, Lord Diplock would have none of this ([1980] 1 WLR 142, 161-162): 'Lord Denning ... was unwilling to accept that the majority speeches ... in McShane had expressed a clear opinion that the test of whether an act was done in furtherance of a trade dispute was purely subjective. This led him to conclude that this House had not rejected a test based on remoteness that he himself had adumbrated and adopted in three earlier cases ... Among the three tests rejected [in McShane] as wrong in law was the test of remoteness the authorship of which was specifically ascribed in my own speech to Lord Denning. Recognising this, counsel for the respondents has not felt able to support the judgment of the Court of Appeal on this ground either.'

16 [1980] 1 WLR 142, 168.

17 [1980] 1 WLR 142, 169. 
Others commented on these general developments. One academic commentator spoke of:

... the tragic drama of a great judge whose acute sense of rightness has become a conviction of righteousness, whose consciousness of the need for justice has led him to become a self-appointed arbiter in the politics of society and whose desire to draw attention to defects in our law has more noticeably drawn attention to himself. Aided and abetted by the media, whose motives are not coincident with the interests of justice, of the legal system nor of the noble judge himself, the process has accelerated and the Master of the Rolls now takes his daily place alongside the good and bad in the nation's headlines. ${ }^{18}$

Denning's decline coincided with the publication of the first edition of JAG Griffith's The Politics of the Judiciary in 1977. There is no doubt but that this was a powerful and influential book, which obliged all those who believed in judicial independence, orthodox theories of judicial reasoning and the rule of law, to re-examine many of their basic premises. Even if Griffith's targets were simplistic and, in any one sense, easy ones - after all, why should it be a surprise to learn that earlier generations of English judges who had been public school educated, gone to Oxbridge, who had served in the forces and who were often found dining at the Athenaeum ${ }^{19}$ should generally be supporters of the police and private enterprise and should be generally hostile to the rights of trade unions? - he nonetheless had a point. That point essentially was that judges were not - and were not perceived to be - neutral in such matters. Perhaps his real point was that in his view such judges could never be neutral given that they were - in Marxist terms - the embodiment of class interests in a society where labour and capital were in enduring conflict.

Let us take another example from south of the border: Re Tilson. ${ }^{20}$ This concerned the exceptionally sensitive topic of the religious education of the offspring of mixed marriages. Prior to 1922 the position at common law had been that the right of paternal supremacy was recognised. And in custody disputes the Irish courts had for very practical reasons generally followed the rule that boys took the religion of their father and girls that of their mother. There was a supremely practical justification for this rule, for as Gibson $\mathrm{J}$ said in Re Storey, ${ }^{21}$ religion was a matter in respect of which a court must be neutral: "each of the various lawful creeds having equal rights', the Court, he declared, was 'not at liberty

18 Andrews, 'Book review' (1980) 14 Cambrian Law Review 114.

19 As Cozens-Hardy MR memorably said in a letter to the incoming Lord Chancellor Buckmaster in May 1915, 'all judges, without exception, are members of the Athenaeum': see R V F Heuston, Lives of the Lord Chancellors 1885-1940 (Clarendon Press 1987) 269.

20 [1951] IR 1.

21 [1916] 2 IR 328. 
to consider what religion is best for the infant'. ${ }^{22}$ Whatever the general merits and demerits of such a rule, it was at least a rule that could be applied neutrally as between the various religions and was something which bolstered at least the appearance of judicial neutrality.

All of this came to an end with the Irish Supreme Court's decision in Tilson. This was a cause célèbre where the Church of Ireland father had given a pre-nuptial promise to the Roman Catholic mother that, in line with the papal Ne Temere decree, the children would be raised as Roman Catholics. When the ensuing custody dispute ultimately came before the Supreme Court, that Court ultimately held that the common law rule was contrary to Article 42.1 of the Irish Constitution which speaks of the right of 'parents' to the care and custody of their children. The reasoning of the Court - which I think has been much misunderstood 23 - is admittedly controversial and the result certainly caused much dismay and grief to the Protestant communities in the Republic. The question, however, which I wish to pose is this: would it have been permissible for the court to take the potentially harmful consequences of its decision for a (at least on one view, beleaguered) minority community into account? Or should it simply have applied the constitutional text neutrally - as in a sense it purported to do - and be indifferent as to the result? After all, the constitutional text does say 'parents' - plural - so that a pre-1937 common law rule which assigns this task to the father alone is difficult to square with this constitutional provision. And if you say that the court could have had regard to those consequences, then one must reckon with an argument with the shade of Lord Denning. Why was it not permissible for him to have regard to (what he would certainly have said was) the baneful consequences of the trade union legislation?

\section{SOME JUDICIAL DILEMMAS}

I propose to return to this wider question presently because I want now to explore another aspect of this judicial neutrality which is, I think, both imperfectly understood and under-explored in the legal literature. As I have already indicated, the classic theory of judging is that, following approximately the scientific method, judges should decide without fear or favour and (implicitly at least) that they should not have regard to the consequences of their decisions. But, in the real world the situation is not quite as straightforward. Judges are not so Olympian or detached from reality that they are immune from psychological pressures, invariably self-generated by personal doubt

23 See, generally, G Hogan, 'A fresh look at Tilson's case' (1998) 33 Irish Jurist 311. 
and personal concerns about the implications of their decisions and perhaps especially - how they will be perceived by their legal peers. Let us first briefly explore a series of judicial dilemmas to see how they were resolved and which each in their own way illustrate the psychological pressures of which I have spoken.

\section{The Abrams case: the dilemma of Oliver Wendell Holmes}

Let us first examine a number of historical examples of these judicial dilemmas. The first I have chosen was the dilemma faced by Oliver Wendell Holmes in Abrams $v$ United States. ${ }^{24}$ In the period immediately after the end of the First World War, the US Supreme Court was faced with the first wave of free speech cases brought by motley groups of communists and anarchists who were convicted of offences under the Espionage Act for urging support for Soviet Russia. It was in this case that Holmes penned his famous dissent championing the First Amendment and free speech:

... but when men have realised that time has upset many fighting faiths

... the ultimate good desired is better reached by free trade in ideas

- that the best test of truth is the power of the thought to get itself accepted in the competition of the market, and that truth is the only ground upon which their wishes can safely be carried out. That, at any rate, is the theory of the Constitution. 25

The prospect, however, of a dissent on this sensitive issue alarmed many of his colleagues. A few days before the dissent was to be delivered in November 1919 a delegation from his colleagues came to see him:

Holmes' colleagues McKenna, Pitney and Van Devanter appeared at the doorstep of 1720 Eye Street. With Mrs. Holmes joining them in the study, they urged him politely but in no uncertain terms not to go through with his planned dissent given Holmes' great reputation and military record ... it would do great harm which he perhaps was unaware of ... ${ }^{26}$

Even though his wife said that she completely agreed with them 'Holmes made clear his mind was made up'. Yet:

In the shadow of the Red Scare and the vehement disapproval of much of the legal profession and indeed much of the country, Holmes staked his reputation - Boston Brahmin, Civil War hero, pre-eminent legal scholar, distinguished judge - to defend freedom of speech for communists, pacifists and foreign-born anarchists. ${ }^{27}$

24230 US 616 (1919). See, generally, M I Urofsky, Dissent in the Supreme Court: Its Role in the Court's History and the Nation's Constitutional Dialogue (Pantheon Books 2017) ch 6.

25250 US 616 at 630.

26 S Budiansky, Oliver Wendell Holmes, A Life in War, Law and Ideas (W W Norton \& Company 2019) at 390.

27 Ibid 460-461. 
And, as Collins has observed, Holmes' indefatigable adherence to his convictions meant that 'Free speech in America ... was never the same after $1919 \ldots . .28$

\section{The Childers case: the dilemma of Sir Charles O'Connor MR}

Our second example comes from November 1922 at the height of the Irish Civil War. The then Master of the Rolls, Sir Charles O'Connor, presided over a habeas corpus application brought on behalf of Erskine Childers. ${ }^{29}$ Childers was a noted author who had in fact been secretary to the Irish Treaty delegation to Downing Street in December 1921, but who later had taken the side of the Anti-Treaty rebels. Childers had been sentenced to death by a military court for the unlawful possession of a pistol in breach of a resolution which had been approved by Dáil Éireann that September. Childers' fundamental argument was that such a prohibition could only have been imposed by Act of Parliament - and not by resolution - and it was irrelevant that the Dáil would only enjoy the power to legislate in the true sense once the Irish Free State was itself established. 30

The Civil War had itself commenced with the shelling of the Four Courts in June 1922, so that at the time the courts were scattered around the City of Dublin. O'Connor delivered his judgment by candlelight in a Kings' Inns guarded by Free State troops following a four-day hearing. His bristling sense of indignation as he rejected the application still rings through the decades almost 100 years later:

I am sitting here in this temporary makeshift for a Court of Justice. Why? Because one of the noblest buildings in the country, which was erected for the accommodation of the King's Courts and was the home of justice for more than a hundred years, is now a mass of crumbling ruins, the work of revolutionaries, who proclaim themselves soldiers of an Irish Republic. I know also that the Public Records Office (a building which might have been spared even by the most extreme of irreconcilables) has been reduced to ashes, with its treasures, which can never be replaced ... If this is not a state of war, I would like to know what is. ${ }^{31}$

O'Connor, however, refused an application for a stay on the execution order even though the Court of Appeal was just about to hear an appeal in a similar case in a few days' time. Childers was executed at dawn

28 Ronald K Collins, Fundamental Holmes: A Free Speech Chronicle and Reader (Cambridge University Press 2010) at 376-377.

$29 R$ (Childers) $v$ Adjutant General, Provisional Forces [1923] 1 IR 5. See, generally, Ronan Keane, 'The will of the general: martial law in Ireland, 1535-1924' (19901992) 25-27 Irish Jurist 151; G Hogan, 'Hugh Kennedy, the Childers habeas corpus application and the return to the Four Courts' in C Costello (ed), The Four Courts: 200 Years (Four Courts 1996) 171.

30 Which occurred one month later on 6 December 1922.

31 [1923] 1 IR 5, 13-14. 
within hours of the delivery of O'Connor's judgment while an appeal was pending.

O'Connor was appointed as a judge of the first Supreme Court in June 1924 but he resigned suddenly in the following April 1925 when he and his wife moved to London. It would seem that both he and his wife suffered a sort of mental breakdown as a result of what he had come to believe was his failure of nerve in the Childers case. ${ }^{32}$ But, if it brings any comfort to his haunted shade, I think that it is easy to be too critical of O'Connor. The entire atmosphere was an intimidating one - a King's Inns building guarded by Pro-Treaty troops and a hurried judgment delivered by candlelight - and the case had engendered raw passions. If the point raised by Childers was correct, a key part of the Government's armoury in the course of the Civil War would have been lost, leading potentially to use of extrajudicial methods on the part of the Free State to counter the Anti-Treaty side's lack of compunction in these matters, and leading possibly to the strangling of democratic institutions at their birth. Was O'Connor haunted by his pragmatic response?

\section{Liversidge $v$ Anderson: the dilemma of Lord Atkin}

Our third example is also from war-time: the celebrated dissent of Lord Atkin in Liversidge $v$ Anderson. ${ }^{33}$ In doing so, I recall that the late Lord Kerr, when delivering this lecture eight years ago, referred to Lord Atkin's celebrated aphorism in Liversidge $v$ Anderson, 'amidst the clash of arms, the laws are not silent' which Lord Kerr observed acted as:

... an inspiration to today's judges in the solemn duty that they must perform in, to quote Lord Atkin again, 'stand[ing] between the subject and any attempted encroachments on his liberty by the executive, alert to see that any coercive action is justified in law.' 34

In Liversidge $v$ Anderson the central question posed was did the Government have to give reasons for its detention of the plaintiff under the regulation 18B internment powers? As you will all know, a majority of the House of Lords said 'no'. Atkin delivered a majestic dissent saying that the arguments of the Attorney General might comfortably have been addressed to the judges of Charles I. He added for good measure:

32 Or, as his biographer put it, 'for undisclosed urgent domestic considerations': see Robert D Marshall, 'Charles Andrew O'Connor', Dictionary of Irish Biography vol 7 (Royal Irish Academy 2009) 235.

33 [1942] AC 206.

34 Lord Kerr at the Lord MacDermott Lecture, 'Human rights law and the "War on Terror”, Queen's University, Belfast, 2 May 2013, 3-4. Or, as Lord Diplock, famously put it, the majority were 'expediently and, at that time, perhaps, excusably, wrong and the dissenting speech of Lord Atkin was right': Inland Revenue Commissioners v Rossminister Ltd [1980] AC 952 at 1011. 
I know of only one authority which might justify the suggested method of construction. 'When I use a word,' Humpty Dumpty said, in rather a scornful tone, 'it means just what I choose it to mean, neither more nor less.' 'The question is,' said Alice, 'whether you can make words mean so many different things.' 'The question is,' said Humpty Dumpty, 'which is to be the master, that's all.' After all this long discussion the question is whether the words 'If a man has' can mean 'If a man thinks he has'. I have an opinion that they cannot and the case should be decided accordingly. 35

Thanks to the work of Heuston and others, 36 the story of how Atkin had to resist pressure from the then Lord Chancellor Simon to change the draft judgment by omitting the 'Humpty Dumpty jibe' before the judgment was delivered is generally well known. The fact that the author of the majority judgment, Viscount Maugham, took the unprecedented step of writing to The Times in defence of the Attorney General and that the entire issue was later made the subject of an (again, at the time, unprecedented) parliamentary debate in the House of Lords is also a matter of public record.

But what I find intriguing about this entire episode is what happened afterwards. Atkin appears to have been snubbed by his colleagues, many of whom it seems never really spoke to him again prior to his death in June 1944:

... the Law Lords refused to eat with Atkin in the House of Lords or, at one point, even to speak to him. Many felt that he never really recovered from his treatment before his death in 1944.37

In his biography of Atkin Lewis maintains that Atkin was unperturbed by this entire affair and points to the fact that in correspondence with friends dating from this period he was more interested in describing the details of a fascinating hand of bridge which he had recently played one evening than giving his account of the controversy. ${ }^{38}$ Yet it is hard to avoid the conclusion that the event must have been profoundly destructive of the friendship and collegiality which is indispensable in an appellate court. The central question here is whether Atkin would have taken this step had he but foreseen the extent of the counterreaction from his colleagues. If he did - or if, like Holmes in Abrams, he was prepared to take the risk - then this bespeaks judicial bravery of an exceptional kind.

35 [1942] AC 206 at 245.

36 R V F Heuston, 'Liversidge v Anderson in Retrospect' (1970) 86 Law Quarterly Review 33; Heuston (n 19 above) 58-60.

37 Robert Stevens, Law and Politics: The House of Lords as a Judicial Body, 18001976 (Weidenfeld \& Nicolson 1976) 287.

38 Geoffrey Lewis, Lord Atkin (Hart 1999) 142. 


\section{The dilemma of (the fictional) Redmond $\mathbf{J}$ in The Heather Blazing}

Atkin's courage may be contrasted with (the fictional) Redmond $J$ in Colm Toibín's great novel, The Heather Blazing. In this novel we learn that Eamon Redmond has grown up in a staunchly nationalist Fianna Fáil background in County Wexford. In his twenties and thirties he is closely associated with the party and, as his career at the Bar prospers, he eventually appears for the State in many of the major constitutional cases from this period. Toibín describes how Redmond came to be appointed to the High Court following an apparently chance encounter with the then Minister for Finance, Charles Haughey TD, at a Dublin restaurant - presumably sometime in the late 1960s. Following some light-hearted banter:

Haughey gave him a mock punch in the chest and grinned.

'You're for the bench', Haughey said.

Eamon said nothing but held his stare.

'Will you take if you're offered it?,' Haughey asked.

'I will,' Eamon said.

'I'll see you soon,' Haughey said. 'It's good to meet you again.'39

While one might query whether these informal methods of judicial appointment would meet modern requirements in respect of judicial independence as recently articulated by both the European Court of Human Rights ${ }^{40}$ and the Court of Justice ${ }^{41}$ respectively, the real point of the story for our purposes comes when Redmond $J$ wrestles with the idea of finding for the plaintiff in a major cause célèbre involving the dismissal of a schoolteacher from a Catholic school in a small rural town because she was living with a married man. ${ }^{42}$ Redmond ultimately thinks the better of it, in part because of concerns about what his colleagues might think:

The family, according to the Constitution, was the basic unit of society. What was a family? The Constitution did not define a family, and, at the time it was written, in 1937, the term was perfectly understood: a man, his wife and their children. But the Constitution was written in the present tense. It was not his job to decide what certain terms ... such as

39 Colm Toibín, The Heather Blazing (Picador 1992) 222.

40 Astradasson $v$ Iceland CE: ECHR: 2020: 1201.

41 See, eg, Case C-896/19 Repubblika EU: C: 2021: 311.

42 This fictional case is loosely based on the facts of Flynn $v$ Power [1985] IR 648. Following the death of the retired former President of the Irish High Court, Hon Mr Justice Declan Costello - who was the trial judge - Toibin published a revised edition of The Heather Blazing in 2012 with the revised version of the novel even more closely resembling the facts of Flynn $v$ Power: see, generally, Barry Sullivan, 'Just listening: the equal hearing principle and the moral life of judges' (2016) 48 Loyola University Chicago Law Journal 351, 397-403. 
'the family' had meant in the past. It was his job what these terms meant now. This woman was living with a man in a permanent relationship, they were bringing up a family ... In what way were they not a family? They were not married. But there was no mention of marriage in the Constitution.

He thought about it for a while and the consternation it would cause his colleagues, a definition of the concept of the family. The teacher would have to win the case then, and the nuns would have to lose. The idea suddenly seemed plausible, but it would need a great deal of thought and research. It had not been raised as a possibility by counsel for the teacher. Lawyers, he thought, knew that he was not the kind of judge who would entertain such far-fetched notions in his court. If he were another kind of person he could write [that] judgment ... ${ }^{43}$

I cannot help thinking but that in this passage Toibín shows an acute understanding of judicial psychology. Unlike Atkin in Liversidge, Redmond is deterred from doing what he is worried may be the right thing by a consideration of how his colleagues would react. Again, let us not be too hard on Redmond. The views of our peers are important, and it is those views which often save us from impulsive and foolish choices which we might otherwise have made, and this is as true of law and judging as it is of life. At the same time, undue deference to collegiate views often leads to group-think and slavish adherence to conventional wisdom when independent judgment is called for.

One way or another these various judicial dilemmas illustrate that, in practice at least, judging is an art and not a science in the sense of the automatic application of autonomous principles similar to mathematical equations or chemical formulae. Holmes had famously said as much in those celebrated opening lines of The Common Law. But if the life of the law is experience, it must just as easily have been influenced by judicial psychology. 44

43 Toibín (n 39 above) 91-92. Emphasis supplied. It is interesting to note that, while the Irish Supreme Court had previously stated that the reference in article 41 of the Irish Constitution to the family was to the family based on marriage (see, eg, The State (Nicolaou) v An Bord Uchtála [1966] IR 567), recently there have been strong signals that the argument which the fictional Redmond $J$ was toying with has been gaining sway: see, eg, the judgment of McKechnie J in Gorry v Minister for Justice [2020] IESC 55.

44 See also Michael McDowell SC, 'Reflections on the limits to the law's ambitions' in B Ruane, J O'Callaghan and D Barniville (eds), Law and Government: A Tribute to Rory Brady (Round Hall 2014) 31-39. 


\section{HOW COULD JUDGES PROPERLY TAKE ACCOUNT OF THE CONSEQUENCES OF THEIR DECISIONS?}

As I have grown older, I find myself increasingly drawn to the doctrine of textualism. If law is the 'articulate voice of some sovereign or quasi-sovereign that can be identified', 45 then in western democratic societies at least we can generally hear it only through the written words of legislation enacted by Parliament or legislative assemblies in the exercise of their democratic mandates. All of this means that judges should not readily depart from the ordinary meaning of the legislative text because to do so would effectively involve the rewriting of that text, thereby undermining the legislative - and, ultimately, the democratic - process. ${ }^{46} \mathrm{~A}$ further consideration is that the private citizen can only really regulate their affairs - if needs be, with the benefit of legal advice - by reference to the actual legislative text. The key word here is 'readily': because, of course, rules as to context (such as noscitur a sociis), purpose and object often serve to leaven the bare words of the legislative text.

One objection to this approach was set out by a judge of the Irish High Court, Humphreys J, in a very interesting paper written in 2017. Drawing on the work of Posner and Weaver, Humphreys posited two general approaches to legal interpretation. The first was what he called the 'doll's house' theory of law:

That approach sneers at what it calls 'result-oriented jurisprudence' and clasps to its bosom the concept of fiat justitia, ruat caelum. Justice must swing her sword blindly and leave it to the 'little people' to pick up the pieces. Decisions that unleash particularly egregious consequences are sometimes accompanied by a disclaimer such as that the court is unfortunately coerced by 'the law' into the particular result, as if the law were some objective, monolithic certainty ... ${ }^{47}$

Humphreys continues by saying that:

Legal rules are an implementation of a social contract and those called upon to interpret that social contract (principally the judiciary) must

45 Southern Pacific Co v Jensen 244 US 205 (1917), 223, per Holmes J.

46 As an aside, that is why I consider that departing from the text to look at parliamentary debates in the manner originally sanctioned by Pepper $v$ Hart [1993] AC 593 is, in the main, undesirable because it dilutes the importance of the actual legislative text. As Lord Hobhouse said in Robinson $v$ Secretary of State for Northern Ireland [2002] UKHL 32, [2002] NI 390 at 413: 'It is fundamental to our constitution and the proper ascertainment of the law as enacted by Parliament that the law should be found in the text of the statute, not in the unenacted statements or answers of ministers or individual parliamentarians. This requirement is simply an a fortiori application of the rules for the proper recognition of what are and are not sources of law and the construction of written instruments.'

47 Humphreys (n 12 above) 62. 
put front and centre that ... interpretative and adjudicative decisions have real-world effects on real people. A theory of adjudication ... that has negative, even disastrous and anarchic, results in the real world is generally to be regarded as a failure; insidiously so where the anarchic decision bestows glistening rights on individuals who, as a matter of fact, are behaving in anti-social or lawless manner, at the expense of their victims or, in a more diffuse way, of law-abiding members of society. 48

Irrespective of one's views on the matter, this is a particularly valuable analysis because it is rare that one finds a judge expressly arguing that courts must have regard to the consequences of their decisions in arriving at a decision, even if since the emergence of the realist school there are many who contend that this is what many judges actually do. Certainly, if courts are going to have regard to the wider policy considerations/consequences in their judgments it would be preferable that such were openly articulated, rather than remaining as a silent unarticulated premise which potentially distorts the reasoning process. But if this can properly be done at all, how would this work? Allow me to take five examples - drawn from each side of the border - and for this purpose conduct a sort of very rough and ready thought experiment. 49

\section{Example 1: Moynihan v Moynihan}

In about 2013 I heard the late Adrian Hardiman50 start a lecture by telling the story of how as a young junior he was asked to write an opinion in respect of a plaintiff who had suffered horrible and lifechanging injuries as a result of an industrial accident. In the opinion Hardiman expressed considerable sympathy for the plight of the plaintiff but argued that, as he could discern no negligence on the part of the employer, he thought that the plaintiff had no case. His more worldly wise silk gently told him to put the opinion away, because no jury ${ }^{51}$ would reach that conclusion. The case was subsequently settled by the employer's insurer and in many ways the road to O'Keefe $v$ Hickey 52 started at that point.

This latter case concerned the question of whether the State could be held vicariously liable for the sexual abuse perpetrated by a teacher at a Catholic school, but which was one nonetheless which had been in

48 Ibid 63.

49 It is very rough and ready because, to do this properly, one would need to survey perhaps hundreds of examples. But these five examples may nonetheless highlight the point I wish to make.

50 Judge of the Irish Supreme Court 2000-2016.

51 In the Republic juries in personal injury cases were only finally abolished in 1988 by the Courts Act 1988 .

52 [2008] IESC 72, [2009] 2 IR 302. 
receipt of public funds. A majority of the Irish Supreme Court rejected the vicarious liability argument, but what is of interest for our purposes is the treatment found in Hardiman J's judgment of an earlier decision of that Court in Moynihan v Moynihan. ${ }^{53}$ In that case a small child was injured in her grandmother's house, to which her parents had brought her, when she pulled down a pot of tea on herself. The tea had been made by her aunt who had then left the room to answer the telephone.

A majority (O'Higgins CJ and Walsh $J$ ) of the Supreme Court held that the aunt who had made the tea was under the de facto control of the grandmother, so that the latter could be made vicariously liable for the negligence of her daughter. There was, however, a dissent from Henchy J:

Much as one might wish that the law would allow this plaintiff to recover damages from some quarter for the consequences of the unfortunate accident that befell her, the inescapable fact is that there is $a$ complete absence of authority for the proposition that liability should fall on the defendant (who was innocent of any causative fault) rather than on Marie whose conduct is alleged to have been primarily responsible for the accident. I see no justification for stretching the law so as to make it cover the present claim when, by doing so, the effect would be that liability in negligence would attach to persons for casual and gratuitous acts of others, as to the performance of which they would be personally blameless and against the risks of which they could not reasonably have been expected to be insured. To transfer or extend liability in those circumstances from the blameworthy person to a blameless person would involve the redress of one wrong by the creation of another. It would be unfair and oppressive to exact compensatory damages from a person for an act done on his behalf, especially in the case of an intrinsically harmless act, if it was done in a negligent manner which he could not reasonably have foreseen and if - unlike an employer, or a person with a primarily personal duty of care, or a motor-car owner, or the like - he could not reasonably have been expected to be insured against the risk of that negligence. ${ }^{54}$ (emphasis supplied)

Hardiman $\mathrm{J}$ was later to point to this dissent in his own judgment in O'Keefe $v$ Hickey:

It is of course almost inconceivable that an infant plaintiff suing by her father would sue the father's mother, the infant's grandmother, if it were anticipated that that lady, a widow, would have to pay the damages herself. It seems inescapable that the action was taken in the hope of accessing an insurance policy, perhaps the grandmother's household insurance. In any event, the majority judgment proceeded on the basis of an elaborate legalistic analysis of the entirely casual relationship whereby the defendant's daughter had made a pot of tea in her mother's house, where she herself lived. What, it is speculated, if 
the daughter were an employed domestic servant or a contractor? (But she was neither). An elaborate analysis, in my view highly artificial, took place of the relationship leading to an adult daughter making a pot of tea in her family home ...55

Warming to this theme on the issue of the distortion of the law, Hardiman $\mathrm{J}$ continued:

It may be noted that the plaintiff in Moynihan had not sued her aunt, the person alleged to be directly negligent, but only the grandmother, hoped to be a 'deep pocket'. The case appears to me to be an early example of the dismantling or muddying of the long established boundaries or limits of vicarious liability. This was done for the very humane reason of helping an innocent injured party to recover compensation, but it was done at a very considerable social cost, not often considered or discussed ... In all cases where there is a serious injury to an innocent person, there is a human tendency to wish that that person should be compensated. But the social and economic consequences of providing a law so flexible that it can be used to provide compensation in the absence of liability in the ordinary sense is addressed in the judgment of Henchy J. 56

This is an unusual - almost unprecedented - example of where one judge had expressly contended that his colleagues had previously distorted the law in order to secure a particular result, in this case, the provision of compensation of the injured little girl. It is, I think, difficult to stand over the vicarious liability aspects of the majority decision in Moynihan and, irrespective of its criticism by Hardiman J in $\mathrm{O}$ Keefe $v$ Hickey, it is a decision which has engendered little subsequent enthusiasm. 57

Like all of you present, I am all in favour of the provision of compensation to little girls who have been scalded by boiling teapots. The difficulty with Moynihan, however, is that in their desire to secure that result, the majority appear to have been tempted to expand the law on vicarious liability with potentially adverse consequences for other and for future cases. In its own way it shows the difficulties associated with result-oriented jurisprudence.

\section{Example 2: R (Hume) $\boldsymbol{v}$ Londonderry JJ}

The background to this seminal case is well known. In $R$ (Hume) $v$ Londonderry JJ58 the late John Hume and others challenged the legality of their arrest and conviction following a civil rights protest at Derry/Londonderry. They challenged the validity of a statutory

55 [2009] 2 IR 302, 318.

56 Ibid 319.

57 See, for example, the observations of B M E McMahon and W Binchy, Law of Torts (4th edn, Bloomsbury Professional 2013) para 43.109.

58 [1972] NI 91. See, generally, B Hadfield, 'A constitutional vignette: from SRO 1970241 to SI 1989 509’ (1991) 41 Northern Ireland Legal Quarterly 54. 
instrument made under the Civil Authorities (Special Powers) Act (NI) 1922 which allowed a member of Her Majesty's forces on duty to effect an arrest where it was suspected that an assembly of three or more persons might lead to a breach of the peace. The Queen's Bench Division held that this legislation was ultra vires the Northern Ireland Parliament given that section 4(1) of the Government of Ireland Act 1920 had prevented that Parliament from legislating on military matters. Fresh emergency legislation was necessary to restore the status quo ante so that the British Army could in fact act in aid of the civil power, ${ }^{59}$ and section 1 of the Northern Ireland Act 1972 was thus enacted within a matter of hours.

But let us leave the merits of that legislation to one side for the moment. How does this decision fit into Posner's argument - as narrated by Humphreys - that for judges to say that they are coerced by 'the law' amounts to the 'theory of power without responsibility'?60 Putting it more prosaically: to what extent should the members of the Court 61 have had regard to the consequences of its decision? And if they did not, would this have been another example of a judgment with 'downstream consequences of chaotic situations unleashed by judgments ...' being regarded as an 'unimportant and an essentially janitorial problem with which the Olympian judge is generally unconcerned?'62

Looking back, it is clear that the Court in Hume did not have regard to the consequences of its decision. The Court would, of course, have been perfectly aware of the consequences which were to flow from its judgment and that fresh legislation would have been immediately required. For my part, I consider that the judgment represented an entirely correct application of the rule of law. Westminster had clearly forbidden the Parliament of Northern Ireland from legislating on such topics and the Queen's Bench Division duly gave effect to that parliamentary command.

So far as the consequences were concerned, it is impossible to deny that - irrespective of one's views on the conflict itself - the support of the British Army of the civil power was necessary and it could not have been simply withdrawn at the stroke of a pen. Should therefore the court have sought to uphold those provisions of the Special Powers Act on the basis that to do otherwise would have brought about these undesirable consequences? For me, the answer is surely not. Any endeavour by the

59 The Attorney General (Sir Peter Rawlinson) told the House of Commons that the decision had left the army 'without essential powers which enable it to discharge the duties for which it was sent to Northern Ireland' HC Deb 23 February 1972, vol 831, col 2364.

60 Richard A Posner, Overcoming Law (Harvard University Press 1995) 124.

61 Lowry LCJ, Gibson and O’Donnell JJ.

62 Humphreys (n 12 above) 61. 
court to fix the problem itself would have risked the obvious distortion of the law in the manner which was, I suggest, discernible in Moynihan. And besides, how could the Court have known what the proper answer should have been, even if one has regard to the social contract theory? Given the realities which prevailed in Northern Ireland in 1971 and 1972 one could, I suppose, have posited a wide variety of possible responses, ranging from assuming that Parliament would have wanted the army to enjoy the full range of police powers on the one hand to very limited functions on the other. As Lord Lowry LCJ remarked admittedly in respect of the second issue of reasonableness which the Court ultimately did not have to decide - this was an intensely political question which no court could possibly answer. 63

\section{Example 3: Bohill $v$ Police Service of Northern Ireland}

Our third example is Bohill v Police Service of Northern Ireland. ${ }^{64}$ Here the applicant was a former police officer who had given distinguished service over a 30-year period. He then applied to a recruitment agency for temporary work as an investigator with the Police Service of Northern Ireland, but despite his name having appeared on a panel on some 13 occasions he was never selected for this work. He contended that he had been discriminated against on grounds of his religious beliefs or political opinions. The essential question, however, was whether the Fair Employment Tribunal had jurisdiction to entertain his claim under the terms of the Fair Employment and Treatment (Northern Ireland) Order 1998.

The Court of Appeal concluded that it had not. As Coghlin LJ observed, given that the tribunal was the creature of statute, it followed that the claimant "must show that he comes within one of the relevant concepts defined within the provisions of the 1998 Order so as to confer jurisdiction upon the Tribunal to hear and adjudicate upon the substantive merits of his claim'. But the Tribunal's jurisdiction was confined to hearing claims brought by 'employees', which term was itself defined as extending to persons who were either employed or who had a contract for services. Yet, as Coghlin LJ observed, the appellant fell into neither category:

[11] ...While the respondent might arguably fall within the definition of 'employer' contained in Article 2 of the Order, the difficulty faced by the appellant is bringing himself within the definition of 'employee'. In the event that the appellant had been selected as a temporary worker by the respondent he would have signed a document constituting a contract

63 [1972] NI 91, 117, quoting Lord Pearson in McEldowney $v$ Forde [1971] AC $632,655$.

64 [2011] NICA 2. I am very grateful to Professor Brice Dickson for drawing my attention to this case. 
for services between himself and the recruitment agency Grafton Ltd. to the period during which those services were supplied to the respondent. At no time would he have been employed under a contract of service either by the respondent or by Grafton. Unless and until his name had been put forward by Grafton and accepted by the respondent the appellant would not have been in any contractual relationship with either Grafton or the respondent. In such circumstances, the appellant was not a person who was seeking employment with the respondent within the meaning of the order.

It followed that the tribunal lacked jurisdiction to hear the claim:

[18] For the reasons set out above this appeal must be dismissed but the case does seem to illustrate how an agency arrangement may deprive potential employees of important protections against discrimination. Northern Ireland enjoys a well deserved reputation for the early development and quality of its anti-discrimination laws and this is an area that might well benefit from the attention of the section of the office of OFM/DFM concerned with legislative reform. We emphasise that, as a consequence of the lack of jurisdiction, we are unable to give any consideration to the substance of the appellant's case.

To my mind, the reasoning and analysis found in this judgment is impeccable. Viewed objectively, most people would, I am sure, agree that it was unfair that Mr Bohill had no effective opportunity of having the merits of his claim tested in this fashion. Yet the words of the definition of employee in Article 2 of the 1998 Order were pellucidly clear. And unless words cease to have any meaning at all, I fail to see how the Court of Appeal were not bound to arrive at the result which they did.

\section{Example 4: O'Neill $v$ Minister for Agriculture and Food}

My next example is O'Neill $v$ Minister for Agriculture and Food.65 In 1947 the Irish Parliament enacted a rather short item of legislation dealing with the grants of licences in respect of the artificial insemination of cattle. In the late 1950s the Department of Agriculture decided upon an extra-statutory scheme whereby for this purpose the State was divided into nine regional geographical areas. The Minister then adopted a policy of granting a regional monopoly to one licensee in each region. In O'Neill the applicant successfully challenged the vires of this licensing system. If one leaves aside some specific features of Irish constitutional law and EU competition law, any UK public lawyer would immediately recognise the specific features of this judgment. The parent Act did not envisage the creation of regional monopolies and the Minister's power to grant exclusive licences on this geographical basis was clearly influenced by unlawful policy considerations. 
The comments made by Keane $J$ are nonetheless of some interest. While he found that the scheme was plainly ultra vires, he nevertheless regretted arriving at this conclusion:

I reach these conclusions with regret. The evidence in the High Court established overwhelmingly that some scheme of this nature was essential if the practice of artificial insemination was to be both controlled and facilitated in the interests of an industry of paramount importance in the Irish economy. This Court is solely concerned, however, with the legality of the scheme and, for the reasons already given, I am forced to the conclusion that it was ultra vires the Act of 1947 and, in any event, could only have been carried out in the form of regulations made under that Act. 66

In passing it might be said that these comments represent a paradigmatical example of the Sumption theory that, while all judges start from an intuitive answer and work backwards, they generally 'recoil in the face of intellectual difficulty or constitutional principle'. It could be said that in O'Neill the Irish Supreme Court might not have wanted to invalidate this scheme, but recoiled from this conclusion when it became clear that to do otherwise would have offended standard constitutional principles.

A bit of background here might nonetheless not be amiss. At least two of the original licensees - Kerry Group and Glanbia - have gone on to become major multinationals in the food and dairy sector. An economic historian might say that this was a successful example of nascent State dirigisme which involved 'picking winners' and giving a major advantage to new emerging companies in this sector which in turn helped them over time on their way to major multinational status. To that extent, those economists might well agree with the comments of Keane J. Other economists might argue that the granting of regional monopolies of this kind simply stifled competition in an important aspect of the food sector and animal genetics and was deeply unfair to both consumers and new entrants alike. Yet judged from the perspective of administrative law, 67 this question does not admit of judicial resolution precisely because, issues of competition law apart, the manner in which a licensing system for the provision of artificial insemination to cattle should operate is ultimately a matter for economic and political judgment.

66 [1998] 1 IR 539, 547.

67 It is admittedly different from a competition law perspective. But, if this is so, it is again because there was then in force either legislative (now Competition Act 2002, ss 4 and 5) or European Union (EU) Treaty (now article 101, article 102, and article 106(2) Treaty on the Functioning of the EU) guidance ordaining that the legality of the actions of either undertakings or (in the case of EU law) domestic legislation be judged by reference to certain defined (largely free market inspired) principles. 
Herein lies my difficulty with the Posner-Humphreys analysis. It would, I suggest, have been wrong for the Supreme Court to have allowed their own views as to what was good or bad for the development of agriculture to colour what essentially was a straightforward legal analysis. Again, at one level, the court's judgment in invalidating a system which had been in operation for almost 40 years could be portrayed as another instance of what Humphreys has described as the 'downstream consequences of chaotic situations unleashed by judgments ...' Yet it was perfectly clear that the Irish Parliament had never sanctioned this exclusivity system and it would essentially have been an affront to the rule of law not to have invalidated it. If, on the other hand, the court had said something like "we think that this system of exclusive geographical licences has worked just fine and, as we do not want to create chaos in the agricultural sector, we will find some adventitious legal principle which will enable us to uphold the vires of the scheme', then this would be open to the objection that legal reasoning was being distorted by the subjective personal preferences of unelected judges in relation to the functioning of the scheme. What, moreover, would happen in the case of a challenge to the next exclusive licensing system where the judges considered that the scheme happened to work, not well, but badly. If that challenge were to succeed on this ground, then the objection would be that judges were deciding cases by reference to their own subjective personal views, the very objection raised by Wechsler68 in the first place.

\section{Example 5: Robinson v Secretary of State for Northern Ireland}

My final example is Robinson $v$ Secretary of State for Northern Ireland. ${ }^{69}$ Here the question was whether the election of Mr David Trimble and Mr Mark Durkan to the positions of First Minister and Deputy First Minister in November 2001 was valid even though this election had taken place beyond the six weeks period following the restoration of devolved government prescribed by section 16(8) of the Northern Ireland Act 1998. In the end, following the decision of Kerr J, a majority of the Court of Appeal and the House of Lords held that the election was a valid one.

For the majority Lord Bingham concluded that these statutory provisions should be interpreted generously, saying that they had the generality of a constitutional provision:

68 H Wechsler, 'Towards neutral principles of constitutional law' (1959) 73 Harvard Law Review 1.

69 [2002] UKHL 32, [2002] NI 390. I am grateful to Professor Christopher McCrudden for this reference. 
The 1998 Act does not set out all the constitutional provisions applicable to Northern Ireland, but it is in effect a constitution. So to categorise the Act is not to relieve the courts of their duty to interpret the constitutional provisions in issue. But the provisions should, consistently with the language used, be interpreted generously and purposively, bearing in mind the values which the constitutional provisions are intended to embody. Mr Larkin submitted that the resolution of political problems by resort to the vote of the people in a free election lies at the heart of any democracy and that this democratic principle is one embodied in this constitution. He is of course correct. Sections 32(1) and (3) expressly contemplate such elections as a means of resolving political impasses. But elections held with undue frequency are not necessarily productive. While elections may produce solutions, they can also deepen divisions. Nor is the democratic ideal the only constitutional ideal which this constitution should be understood to embody. It is in general desirable that the government should be carried on, that there be no governmental vacuum. And this constitution is also seeking to promote the values referred to in the preceding paragraph.

It would no doubt be possible, in theory at least, to devise a constitution in which all political contingencies would be the subject of predetermined mechanistic rules to be applied as and when the particular contingency arose. But such an approach would not be consistent with ordinary constitutional practice in Britain. There are of course certain fixed rules, such as those governing the maximum duration of parliaments or the period for which the House of Lords may delay the passage of legislation. But matters of potentially great importance are left to the judgment either of political leaders (whether and when to seek a dissolution, for instance) or, even if to a diminished extent, of the crown (whether to grant a dissolution). Where constitutional arrangements retain scope for the exercise of political judgment, they permit a flexible response to differing and unpredictable events in a way which the application of strict rules would preclude.

All these general considerations have a bearing, in my opinion, on the statutory provisions at the heart of this case. The parties are agreed that section 16(8) imposes a duty on the Assembly. The parties are also agreed that such duty is mandatory, although further agreeing that the old dichotomy between mandatory and directory provisions is not a helpful analytical tool ... Parliament did intend the Assembly to comply with the six-week time limit laid down in section 16(8). That is why it conferred power on the Secretary of State to intervene if, at the end of that period, no First Minister and deputy First Minister had been elected. It is the answer to the second question which fundamentally divides the parties.

Had it been Parliament's intention that on a failure to elect within six weeks as required by section 16(1) and (8) the Secretary of State should forthwith put arrangements in train to dissolve the Assembly and initiate an early poll for a new Assembly, this could very easily and 
simply have been stated. But this is not what section 32(3) says and such a provision:

(1) would have been surprising, particularly in the context of section 16(1), since little more than seven weeks would have elapsed since the last poll (section 31(4)) and there could be no assurance that a further poll would procure a different result;

(2) would have precluded the possibility of negotiation and compromise to find a political solution to an essentially political problem, contrary (as I would suggest) to British political tradition; and

(3) would have deprived the Secretary of State, acting as the nonpartisan guardian of this constitutional settlement, of any opportunity to wait, even briefly, for a solution to the problem to emerge.

It is difficult to see why Parliament, given the purposes it was seeking to promote, should have wished to constrain local politicians and the Secretary of State within such a tight straitjacket. 70

In his concurring judgment Lord Hoffmann was even more explicit on the issue of the consequences of the decision:

Mr Larkin QC, in the course of his admirable argument for the appellant, politely but firmly reminded your Lordships that your function was to construe and apply the language of Parliament and not merely to choose what might appear on political grounds to be the most convenient solution. It is not for this House, in its judicial capacity, to say that new elections in Northern Ireland would be politically inexpedient. Mr Larkin cited Herbert Wechsler's famous Holmes Lecture, Towards Neutral Principles of Constitutional Law ((1959) 73 Harvard LR 1). My Lords, I unreservedly accept those principles. A judicial decision must, as Professor Wechsler said (at p. 19) rest on 'reasons that in their generality and their neutrality transcend any immediate result that is involved.' But I think that the construction which I favour satisfies those requirements. The long title of the Act is 'to make new provision for the government of Northern Ireland for the purpose of implementing the agreement reached at multi-party talks on Northern Ireland .... According to established principles of interpretation, the Act must be construed against the background of the political situation in Northern Ireland and the principles laid down by the Belfast Agreement for a new start. These facts and documents form part of the admissible background for the construction of the Act just as much as the Revolution, the Convention and the Federalist Papers are the background to construing the Constitution of the United States. ${ }^{71}$

Despite the protests of Lord Hoffmann, some might think that this is a 'consequentialist' approach whereby the Court opted for the most politically convenient solution and worked backwards. For my part,

70 [2002] UKHL [11]-[14], [2002] NI 390 at 398-399.

71 [2002] UKHL [33], [2002] NI 390 at 403-404. 
however, I am not so sure because it does not necessarily follow that just because the six-week time limit was not complied with the consequence that what happened thereafter was thereby void. At the same time it is undeniable that there had been a significant non-compliance with a key statutory provision which Parliament - doubtless for its own good reasons - had seen fit to prescribe.

There is indeed a comparison here with what happened in 1960 and 1961 in the Republic following the High Court's decision72 that legislation enacted in 1959 revising the electoral boundaries was unconstitutional. The Irish Parliament rushed to enact new legislation which respected the High Court's decision. One result of this finding of unconstitutionality was that the constitutional requirement to the effect that the constituencies had to be revised every 12 years ${ }^{73}$ had not been complied with because no valid law had been enacted within that constitutionally stipulated period, as the previous constituency revision had taken place with the Electoral (Amendment) Act 1947. The Irish Supreme Court subsequently held, however, that this omission to comply with that requirement did not affect the constitutionality of the new electoral legislation because:

... if this period has been allowed to elapse without a revision being carried out, the obligation remains to carry it out as soon as possible. There is, of course, a satisfactory explanation in this case. ${ }^{74}$

But what if there had not been a satisfactory explanation? This is where consequentialist reasoning starts to come into play, because it cannot be that the courts would allow the ruat caelum principle to be applied blindly where the fundamentals of the legal order are threatened by a judicial decision with immense consequences, such as where a particular law is held invalid or unconstitutional. In a variety of jurisdictions, the courts have developed techniques ranging from prospective overruling to suspended declarations of unconstitutionality to limit the potentially chaotic consequences of a judicial decision of invalidity. ${ }^{75}$ For my part,

72 O Donovan v Attorney General [1961] IR 114.

73 Article 16.4.2 of the Irish Constitution provides that the Oireachtas (Parliament) 'shall revise the constituencies at least once every twelve years, with due regard to changes in distribution of population ...'.

74 Re Article 26 and the Electoral (Amendment) Bill 1961 [1961] IR 169, 180, per Maguire CJ.

75 This, again, has been the experience of the Irish Supreme Court, particularly in dealing with the aftershocks caused by a finding of constitutional invalidity of a law, precisely because, as Geoghegan $\mathrm{J}$ astutely observed in $A v$ Governor of Arbour Hill Prison [2006] IESC 45, [2006] 4 IR 88 [203], unless courts limited the retroactive and other effects of such a finding, the consequence would be that judges would be less willing to invalidate laws in future: 'there would be a grave danger that judges considering the constitutionality of enactments would be consciously or unconsciously affected by the consequences'. 
however, even in these circumstances any potential remedy should not overbear or distort the substantive decision. Accordingly, rather than saying that 'the consequences would be so bad I must find a way of finding against X on the merits', it is, I suggest, much better to say, for example, that the prison conditions which $\mathrm{X}$ is currently enduring are legally unacceptable even if this finding does not in itself mean that $\mathrm{X}$ must be immediately released. 76

\section{CONCLUSIONS}

Article 1(2) of the Swiss Civil Code famously states that where the court is required to decide a matter not otherwise provided for in the Code or in customary law, it shall decide the matter 'in accordance with the rule that it would make as legislator'.

(2) In the absence of a provision, the court shall decide in accordance with customary law and, in the absence of customary law, in accordance with the rule that it would make as legislator.

(3) In doing so, the court shall follow established doctrine and case. ${ }^{77}$

There is, I think, no equivalent provision in any common law system. And so we return to the question posed at the start: should judges have regard to the consequences of their decisions when adjudicating upon the merits of the case or should they be guided by purely legal factors? Judging is an art, not a science. Pragmatism is a practical human virtue which often represents the better part of valour. One cannot therefore say that pragmatism properly has no role in the judicial process and, even if one did, the reality of human psychology is such that many of us would recognise Eamon Redmond in The Heather Blazing in ourselves. One might also say that the fact that a judgment might have far-reaching consequences is itself a reason which should give a judge an occasion to pause and reflect. In such circumstances it would generally be prudent to re-examine the premises and reasoning of any proposed judgment before arriving at such a decision.

Yet, on the whole, judges are better guided by the application of principle rather than any endeavour to peek behind the blinds of justice and to seek to anticipate the consequences of their decisions and to work backwards in their reasoning. To repeat the words of Neil Gorsuch, any judge who seeks to ensure that the result assorts with their own personal views is likely to be a pretty poor judge and, in that

76 See, eg, Kinsella $v$ Governor of Mountjoy Prison [2011] IEHC 235, [2012] 1 IR 467.

77 G Picht and G Studen, 'Civil Law' in M Thommen (ed), Introduction to Swiss Law (Carl Grossman 2018) 283-284. 
respect at least, Our Lady of the Common Law cannot be fooled. And here, I think, is the nub of the problem with the Posner-Humphreys analysis.

I say that for two reasons.

First, I cannot agree that judges are not bound by the text of the law and, inasmuch as Posner says otherwise, I profoundly disagree. One may fully acknowledge that there are nearly always interpretative choices which are open to judges, but the statement that judges are never bound by the legal text is, with respect, far too dogmatic and wrong, as the decisions in both Hume and Bohill illustrate. And this, after all, was the point with which Lord Scarman could gently chide Lord Denning in Duport Steels. To repeat, legislation is the authentic voice of the legal sovereign and judges can only hear that voice through the application of well-established principles of statutory interpretation. If, for example, legislatures wish to bring about an important legal change the application of the presumption against unclear changes in the law serves to require that this must be done expressly and not in some indirect manner. ${ }^{78}$ So, far from saying that the principle that the court is bound by the legal text to reach a result which Parliament might have never contemplated or intended amounts to the exercise of power without responsibility, I would respectfully contend for the contrary: it is rather the exercise of the judicial power in a manner which is most faithful to the rule of law.

Second, our own thought experiment tends to show, even allowing for the necessarily tiny sample, that the courts cannot satisfactorily seek to cure the deficiencies of legislation or the law generally by ad hoc solutions or by a form of working backwards reasoning. If, for example, you think that the licence exclusivity scheme at issue in O'Neill worked well and that for that reason you seek to uphold its vires by an ad hoc solution, then how do you deal with the next exclusive licensing system that you consider is not working well? More to the point, how do unelected judges make value judgments that are essentially policydriven and legislative-based in character? Most - admittedly not all orthodox economists would, for example, be sceptical of the supposed value of regional monopoly licensing systems as being bad for consumers and as tending to create inefficiencies and as stifling innovation. I dare say that few would disagree with the comments of Coghlin LJ in Bohill to the effect that there were no particular reasons why agency workers should be excluded from the scope of fair employment legislation, but, again, this is ultimately a judgment which a legislature and not judges should make. The Court of Appeal should not have distorted the language of the all too clear provisions of the 1998 Order just because 
they think that this would be fairer and better and even if in that case almost no one would disagree. Unless, therefore, one was going to transpose with some adaptations a provision such as Article 1(2) of the Swiss Civil Code, one must acknowledge that the capacity of the judiciary to effect a sort of running repairs to the legislative machinery is limited.

And so I close with this tentative conclusion: human psychology runs deep and judges are often affected deeply by the facts and circumstances of hard cases with real life consequences. The desire to please, to be collegiate and to be flexible are features of that psychology and it allows us to leaven a certain strict and unforgiving legal logic with a necessary degree of pragmatism and, indeed, common sense. To that extent judges cannot be entirely neutral in the sense of effecting a complete, Olympian detachment from the real-life consequences of their decisions: sometimes, perhaps, expediency has a role. Yet experience has shown that judges are at their best when they act independently of their own personal, subjective views and when they listen only to the authentic voice of the legal sovereign. If psychology and pragmatism means that judges cannot always be neutral, then they should nonetheless strive to be so. 